\title{
Özel Eğitimde Geçmişten Günümüze Hak Savunucular Olarak Aileler
}

\section{The Advocacy Role of Families from Past to Present in Special Education}

\author{
Havva PAMUK*, Meral MELEKOĞLU**
}

\begin{abstract}
Öz: Özel gereksinimi olan çocuğun ailelerinin sahip oldukları özellikler ve çocuklarının gelişim süreci içerisinde üstlendikleri roller, çocuklarının gelişimi ve eğitim süreci için oldukça önemlidir. Bu rollerden biri olan hak savunuculuk rolü ise özel gereksinimi olan çocukların ihtiyaç duydukları hizmetlere erişebilmeleri açısından anahtar niteliğinde görülmektedir. $\mathrm{Bu}$ sebeple, bu makale içerisinde özel gereksinimi olan çocuğa sahip ailelerin işlevleri, rolleri ve özellikle hak savunuculuk rolü üzerinde durulmuştur. Ayrıca tarihsel bağlamda, özellikle Amerika Birleşik Devletleri ve Türkiye'de özel gereksinimi olan çocuğa sahip ailelerin hak savunuculuk rolleriyle ilişkili olarak attıkları adımlar ve bu konuda güncel olarak ailelere destek ve hizmet sağlayan programlar ele alınmıştır. Özel gereksinimi olan çocuklar günümüzde ulusal ve uluslararası düzeyde halen istendik düzeyde özel eğitim hizmetlerine erişim konusunda sorunlar yaşamaktadır. Bu çocukların eğitsel ihtiyaçları yeterince karşılanamamakta ve toplumsal kabul düzeyleri konusunda olumsuz tutumlarla karşı karşıya kalmaktadırlar. Dolayısıyla, olumsuz durumlarla baş edebilmeleri, iyi bir yaşam şartlarının oluşturulması, toplumsal ve politik engellerin ortadan kaldırılması ve tam bir firsat eşitliğinin sağlanması için savunuculuk rolünün aileler tarafından etkili bir şekilde kullanılmasına gereksinim duyulmaktadır.
\end{abstract}

Anahtar Kelimeler: Özel eğitim, özel gereksinimi olan çocuk, aile rolleri, engellilik, savunuculuk.

\begin{abstract}
The characteristics of families of children with special needs and their roles in the development process of their children are very important for the development and education process of their children. One of these roles, the advocacy role, is seen as a key for children with special needs to access the services they need. For this reason, the functions and roles of families of children with special needs, and especially advocacy role are emphasized in this article. In addition, advocacy role of families of children with special needs was discussed in the history context in the United States and Turkey. Support programs and services providing to families have been also discussed. Today, children with special needs still have problems in accessing special education services at the desired level at national and international context. Considering that these children may face negative situations such as meeting their educational needs and social acceptance; the advocacy role should still be used effectively by families to cope with adverse situations, to provide a good living condition, to eliminate social and political barriers and to ensure full equality of opportunity.
\end{abstract}

Keywords: Special education, child with special need, roles of families, disability, advocacy.

\section{Giriş}

Bir çocuğun gelişiminde ve yaşamında önemli bir yere sahip olan aile, toplum temelinde yer alan önemli bir kurum olarak görülmektedir. Çocuğun dünyaya gelmesiyle birlikte ilk etkileşim ve iletişim kurduğu kişiler aileleridir ve bu durum aileyi, çocuğunun yaşamını etkili bir şekilde sürdürmesi açısından önemli kılmaktadır (Tavil, 2005). Alanyazında yer alan aile kavramının anlamına yönelik yapılan tanımlar incelendiğinde, aile ile ilgili olarak evrensel ve tek bir tanım olmadığı ve aile kavramının çeşitli şekillerde tanımlandığı görülmektedir (Cavkaytar, 2012). Örneğin, Bronfenbrenner (1986) aileyi, içerisinde yetişen bireyin gelişimine birçok boyutta katk1 sağlayan temel bir bağlam olarak ifade etmiştir. Başbakanlık Aile Araştırma Kurumu (1990) ise aileyi, bir toplumda hukuki temele dayalı olarak evlilik ve akraba bağlılığı oluşmuş, aynı ortamda yaşayan bireylerden oluşan toplumsal kurum olarak tanımlamaktadır. Alan yazındaki bir diğer

\footnotetext{
*Uzman, Eskişehir Osmangazi Üniversitesi, Eğitim Fakültesi, Eskieşhir-Türkiye, ORCID: 0000-0001-7653-7582, eposta: havva.pamuk1881@gmail.com

**Sorumlu yazar, Dr. Öğr. Üy., Eskişehir Osmangazi Üniversitesi, Eğitim Fakültesi, Eskieşhir-Türkiye, ORCID: 00000003-4349-9959, e-posta: meralmelekoglu@ gmail.com
} 
tanıma göre aile, kişilerin içinde doğmuş oldukları ve yaşamlarının önemli sayılabilecek bir kısmını birlikte geçirdikleri bir tür sosyal bir grubu ifade etmektedir (Cavkaytar, 2012). Yapılan bir başka tanıma göre ise aile, "kişilerin bakımının sağlanması için gerekli sorumlulukları paylaşan, evlilik, kan ya da anlaşmaya dayanan ilişki ya da evlat edinme üzerinden birbirlerine bağlanan toplumsal bir yapı olarak tanımlanmaktadır' (Schaefer, 2013). Poston ve diğerleri (2003) tarafindan yapılan bir tanıma göre de aile, kendilerini aile olarak gören ve genel olarak aile işlevlerini yerine getiren iki ya da daha fazla kişiden oluşmaktadır ve ailelerin evlilik, kan bağ 1 ya da birlikte yaşama zorunluluğu bulunmamaktadır. Yine yapılan bir başka tanıma göre aile, çocuğun kendisini bekleyen hayata hazırlandığı aile tarafından çocuğa iyi, kötü, doğru, yanlış gibi kavramların kazandırıldığı, toplumsal becerilerin öğretildiği, çocuğun doğuştan getirdiği beceri ve yeteneklerini kullanmasında etkili olan toplumsal bir kesittir (Y1lmaz Bolat, Gürsoy ve Strom, 2016). Yapılan tanımlar genel olarak incelendiğinde, aile tanımının geleneksellikten uzaklaşarak toplumsal değişime bağlı olarak değiştiği ve şekillendiği söylenebilir. Tanımlarda genellikler; (1) ailede birden fazla bireyin olmasına, (2) ailenin özellikle çocuklar açısından önemli rolleri üstlenmesine, (3) aile bireyleri arasında kan bağ 1 ve yasal bir durumun olup olmamasına, (4) aile bireylerinin birlikte vakit geçirmesine, (5) sosyal bir grup olmasına ve (6) toplumdaki en küçük yapı taşı olmasına vurgu yapıldığı görülmektedir.

Aile ile ilgili tanımlar değişse de ailenin geçmişten günümüze özellikle bakmakla yükümlü olduğu çocuğuna yönelik işlevlerinde pek bir değişikliğin olduğu söylenemez. Bilindiği üzere bir çocuğun içinde büyüdüğü ailenin temel işlevleri bulunmaktadır (Blacher ve Hatton, 2001). " $\mathrm{Bu}$ işlevler genel olarak; ekonomik ihtiyaçları karşılamak, statü sağlamak, çocukların eğitimini planlamak, din eğitimi vermek, boş zaman faaliyetleri gerçekleştirmek, aile üyelerinin birbirini koruması ve karşılıklı sevgi ortamı yaratmak olarak sayılmaktadır' (Cavkaytar, 2012, s. 9 ). Kır (2011) ekonomik gereksinimleri karşılama işlevine göre aileyi, toplumsal yaşam içerisinde üretim ve tüketim işlevini gören bir birim olarak tanımlamaktadır. Kır'a göre bir aile ekonomik gereksinimlerini karşılamak amacıyla kaynaklarını kendisi üretmekte, ihtiyaçlarını gidermek için de üretiklerini kendisi tüketmektedir. Başka bir ifade ile aile üyelerinin kişisel gereksinimleri aile içinde karşılanmaktadır (Ergün, 1987). Statü sağlama işlevi için aile, kendi içerisinde doğan ve gelişmekte olan bireye doğumdan itibaren bir birey olarak doğal bir sosyal statü sağlamaktadır. Çocuğun ailesinde bu statüyü elde etme biçimi ve düzeyi ailenin sosyo- kültürel ve eğitim düzeyi gibi önemli görülebilecek özelliklerine bağlı olarak farklılık gösterebilmektedir (Kır, 2011). Eğitim işlevine göre ise öncelikle çocuğun eğitiminden aile sorumlu olmakta ve eğitimin temeli ailede atılmaktadır (Cavkaytar, 2012; Kır, 2011). Bir çocuk, aileden almış olduğu eğitim sayesinde kendisini bekleyen gelecekteki hayata ve hayat koşullarına hazırlanmakta ve ileride seçecek olduğu olas1 mesleğe yönlendirilmektedir (Gökçe, 1991). Din eğitimi verme işlevi açısından aile, içindeki üyelerine kendi sahip olduğu dini inançları kazandırmakta, onlara dini ve özellikle ahlaki eğitim sağlamaktadır. Çocuğun din eğitiminin önemli sayılabilecek temel kısmı, aileleri tarafından gerçekleştirilmektedir (Kır, 2011). Boş zamanları değerlendirme işlevi bağlamında aile, içerisinde yer alan üyelerinin her birinin boş zamanlarını aktivitelerle planlamalarını, iyi vakit geçirmelerini, eğlenmelerini sağlamaktadır (Gökçe, 1991; Summers vd., 2005). Aile üyelerinin birbirini koruması işlevinde ise çocuk dünyaya geldiğinde oldukça korumasız bir halde olduğundan aile, çocuğun tüm ihtiyaçlarını gidermekte, çocuğun zarar görmesini engellemek yoluyla çocuğunu korumaktadır (Kır, 2011). Ayrıca bu işlev ile aile, neslin devamını sağlayarak insanlığın varlığını da korumaktadır (Gökçe, 1991). Birlikte karşılıklı sevgi ortamı yaratmak işleviyle ilgili olarak aile, doğal sevginin kaynağı olarak kabul edildiğinden bu ihtiyacın en iyi karşılandığı yer ailedir. Bu işleve göre aile, çocuğunun sevgi ve şefkat ihtiyacını karşılayan bir birim işlevi görmektedir (Tezcan, 1985).

Ailelerin işlevlerini yerine getirmesinde; ailenin demografik yapıs1, sosyo-kültürel etmenler, ekonomik yapısı, ailenin yaşam döngüsü ve aile bireylerin sağlık durumu gibi pek çok etmen olumlu ya da olumsuz yönde etki etmektedir (Cavkaytar, 2012). Buna ek olarak, çocuğun gelişim özellikleri, özel bir durumunun olması, çocuk ve aile arasındaki biyolojik bağlar gibi durumlar 
bazen ailenin işlevinde farklılıklara neden olsa da ailelerin temel işlevlerinde bir değişim söz konusu olmamaktadır (Turnbull, Turnbull, Erwin ve Soodak, 2006). Bu bağlamda, özellikle tipik gelişim gösteren akranlarına kıyasla gelişimlerinde anlamlı farklılık gösteren özel gereksinimi olan çocukların gelişim süreçlerinde ailelerin üstlendikleri roller oldukça önemlidir (İlhan, 2017). Dolayısıyla ailelerin özel gereksinimi olan çocuklara daha fazla zaman ayırmaları gerekmektedir. Buna ek olarak, özel gereksinimi olan çocukların ailelerinin işlevlerinin sayısında ve yoğunluğunda çocuğun bireysel özelliklerine göre farkl1lıklar görülebilmektedir (Cavkaytar, 2012). Bu nedenle özel gereksinimi olan çocukların aileye olan gereksinimi zaman zaman tipik gelişim gösteren çocuklara kıyasla daha fazla olabilmektedir (Aydoğan-Akıncı ve Darıca, 2000). Bu noktada, özel gereksinimi olan çocuğun gelişimi konusunda hedeflenen noktaya ulaşılabilmesi ailelerin rollerini ne düzeyde yerine getirdiği ile doğru orantılı olabilmektedir (Sucuoğlu, 1996).

Özel gereksinimi olan çocuğa sahip aileler, çocuklarının eğitim süreçlerinde üstlendikleri roller aracılığıyla, çocuklarını var olan gelişimleri konusunda yüreklendiren, çocuklarına gerekli bilgileri sağlayan ve rehberlik eden ilk eğitimciler olarak görülmektedir (Hooper ve Umansky, 2004). Özel gereksinimi olan çocuğun kendisi için belirlenen eğitimsel amaçlara ulaşılabilmesi, çocukların gelişimsel ihtiyaçlarının tam anlamıyla karşılanabilmesi ve etkili hizmetlerin sunulabilmesi yaşamın ilk yıllarından itibaren ailenin çocuğunu ne kadar desteklediğine bağlıdır (McGahee, Mason, Wallace ve Jones, 2001). Aileler özel gereksinimi olan çocuklarını çeşitli şekillerle destekleyebilmekte ve bu destekleri sağlarken de farklı düzeylerde çeşitli rolleri benimsemektedirler. Aileler özel gereksinimi olan çocuklarına öğretmenlik yapmak, yetersizlikle ilgili gönüllü kuruluşlarla işbirliği yaparak özel eğitimi ve özel gereksinimi olan çocukların sahip oldukları yetersizlik türlerinin özelliklerini tanıtmaya çalışmaktadır. Buna ek olarak, aileler çeşitli özel eğitim okullarının açılmasında liderlik etmek, politik savunuculuk yapmak, çocukları için eğitimsel kararların verilmesinde rol almaktadır. Aileler ayrıca benzer özelliğe sahip çocukların anne ve babaları ile işbirliği yapmak ya da diğer anne ve babalara çocuklarının eğitimi için rehberlik etmek gibi çeşitli roller üstlenmektedirler (Sucuoğlu, 1996). Ailelerin üstlendikleri bu rollerin doğrudan ve dolaylı yollardan özel gereksinimi olan çocuklarının gelişimlerine katkı sağladığı söylenebilir (Fiedler, Simpson ve Clark, 2007).

Bir aileye, özel gereksinimi olan bir çocuğun dahil olması ile birlikte ailelerin yetersizlikle ilgili bilgi, birlikte vakit geçirme, sosyal ve ekonomik destek gibi konularda çeşitli desteklere gereksinim duydukları görülmektedir (Akçamete ve Kargın, 1996; Meral ve Cavkaytar, 2013; Summers vd., 2005). Özel gereksinimi olan çocuğa sahip aileler, çocuklarının özel gereksinimli birey olarak tanılanması sonrasında karmaşık duygu durumları içerisine girmekte, kimden nereden ve nasıl destek alacaklarını bilememektedirler (Melekoğlu, Kırıcı, Kartal ve Tekin, 2018). Bu noktada, aileler çocukları için alınacak tedbirler konusunda yetersiz kalabilmekte ve çocukları hakkında hak savunuculuğu yapma rolünü benimseyebilmektedir (Burke ve Hodapp, 2016). Özel gereksinimi olan çocuklar için ailelerinin göstermiş olduğu hak savunuculuk rolü, özel gereksinimi olan çocukların ihtiyaç duydukları hizmetleri almalarının sağlanması açısından oldukça önemlidir (Conley Wright ve Taylor, 2014). Özel eğitim alanında ailelerin hak savunuculuk rolünü çeşitli boyutlarıyla ele alan çalışmalar bulunmaktadır (Turnbull vd., 2006; Zaretsky, 2004). Ancak bu konuyla ilgili olarak Türkiye'de yapılmış özel gereksinimi olan çocukların ailelerinin tarihsel süreç içerisindeki hak savunuculuk rolü sürecini ele alan bir çalışmaya rastlanmamıştır. Dolayısıyla bu çalışmada, özel gereksinimi olan çocuğa sahip ailelerin hak savunuculuk rolü, bu rolün önemi ve ailelerin savunuculuk yaparak özel gereksinimi olan çocuklar açısından katkıları ulusal ve uluslararası alanyazın bağlamında tarihsel süreç içerisinde ele alınmıştır.

\section{Hak Savunucular Olarak Aileler}

Günlük yaşamda çeşitli zamanlarda ve durumlarda bir şekilde her birey, haksızlığa uğradığını düşündüğü durumlarda savunuculuk yapabilmektedir. Bu savunuculuk kolay gibi görünse de bireyin savucunuluk yapması her zaman kolay ilerleyen bir süreç değildir. Esasen savunuculuk, 
başka imkanlar aracılığıyla elde edilmesi mümkün olmayan, istendik bir sonucu elde etmek amacıyla bir bireyin var olan kendi bakış açısını ya da başka bir bireyin bakış açısını benimsemesi olarak tanımlanmaktadır (Turnbull ve Turnbull, 2001). Başka bir tanıma göre savunuculuk, önceden belirlenmiş ve amaçlanmış bir hedef için harekete geçmek anlamına gelir ve sorun odaklı bir yapıya sahip olması nedeniyle bir sorunun doğasını, o sorunu çözmenin önündeki engelleri aşmak için mevcut kaynakları gerektiğinde kullanmayı ve olası problemlere ve engellere yönelik olarak yapılacak eylemleri kapsamaktadır (Turnbull vd., 2006). Savunuculuk, konuyla yakından ilgilenen bireyler tarafindan çeşitli ortamlarda veya çeşitli konularda gerçekleşebilmektedir (Turnbull ve Turnbull, 2001). Özel gereksinimi olan çocuklar söz konusu olduğunda ise bu çocukların aileleri, özel gereksinimi olan çocuklar için doğal savunucular olarak görülmektedir (McCammon, Spencer ve Friesen, 2001). Çeşitli gereksinimleri ve destek ihtiyaçları sebebiyle tipik gelişim gösteren akranlarına kıyasla özel gereksinimi olan çocukların haklarının aileleri tarafından savunulma ihtiyacı daha belirgin olarak hissedilmektedir. Dünya geneline bakıldığında ise aile savunuculuğu, özel gereksinimi olan bireylerin etkilenmekte oldukları yetersizliklerle ilişkili olarak yaşadığı olumsuz durumlara karşı gereksinim duyduğu hizmetlere erişimini kolaylaştırmak ve iyileştirmek için etkili bir girişim yöntemi olarak görülmektedir (Cohen, 2013).

Özel gereksinimi olan bireylere yönelik, dünyanın farklı yerlerinde çeşitli şekillerde sunulmakta olan özel eğitim hizmetleri, aile savunuculuğu aracilığıyla desteklenmektedir (Phillips, 2008). Ne var ki özel eğitimde, savunucuk konusunda kişilerin farkındalık ve bilgi düzeyleri çok gelişmiş değildir (Burke, Lee ve Rios, 2019). Bu konuda iyileşme sağlanması amacıyla yapılan bir çalışmada, özel gereksinimi olan bireylerin aileleriyle yürütülen savunuculuk faaliyetlerinde tercih edilen çeşitli savucunuluk türleri ve tanımları ortaya konulmuştur. Trainor'a (2010) göre sezgisel savunucular, yetersizlik uzmanı, sistemik değişimin aracıları ve stratejistler olmak üzere dört savunuculuk türü bulunmaktadır. Sezgisel savunucular, çocukları hakkında kendi içgörülerine itimat etmektedirler. Yetersizlik uzmanları, çocuklarının yetersizliği hakkındaki bilgilere dayanmaktadırlar. Değişim için aracılar, sadece kendi çocukları için değil, aynı zamanda sistem içerisinde daha büyük çaplı ve daha fazla bireyi kapsayan değişimi savunan bireyleri ifade etmektedirler. Stratejistler ise çocuklarını savunmak için yasalar yoluyla kendilerine ve özel gereksinimi olan çocuklarına tanınan hakları anlamaya dayanmaktadırlar. Her tür savunuculuk önemini ihtiyaç duyulma sebebi açısından korusa da "stratejist" savunuculuk türü son derece yaygın olarak özel gereksinimi olan çocuğa sahip aileler tarafindan kullanılmaktadır (Burke ve Hodapp, 2016; Trainor, 2010). Hangisi tercih edilirse edilsin savunuculuk türlerinden birini ya da birden fazlasını benimseyen aileler aracılığıyla özel gereksinimi olan çocuklarla ilgili gereksinim duyulan hizmetleri elde etme konusunda olumlu ve anlamlı yönde gelişmeler sağlanmaktadır (Burke, 2013).

Özel gereksinimi olan çocukların aileleri aracılığıyla yürütülmekte olan savunuculuk faaliyetlerinin aileler ve özel gereksinimi olan çocukları açısından mikro ve makro düzeyde olumlu sayılabilecek çeşitli sonuçları bulunmaktadır (Conley Wright ve Taylor, 2014). Mikro düzeyde savunuculuk, hem çocuk hem de çocuğun içinde bulunduğu ailenin bireyleri için kaliteli sayılabilecek hizmetleri hedeflemektedir. Genellikle bu düzeydeki savunuculuk sadece aile bireylerinin olumlu anlamda etkilenmesiyle sonuçlanmaktadır (Kalyanpur ve Harry, 1999). Bu bağlamda bazı aileler için savunuculuk, yalnızca çocukları için yapılan bir hareket iken, bazı aileler için ise savunuculuk daha politik bir hareket haline gelmektedir. Bu nedenle, aileler özel gereksinimi olan çocukları için daha duyarlı hizmetlere ulaşmak amacıyla diğer ailelerle de işbirliği yaparak daha geniş çaplı kitlelere ulaşmayı hedeflemektedirler (Zaretsky, 2004). Makro dïzeyde savunuculuk ise yasal mevzuata yönelik değişiklikler, çeşitli yetersizlik türlerine yönelik toplum farkındalığ kazandırma, ilgili araştırmaların arttırılması ve etkili hizmetlerin sunumu için daha fazla maddi destek ayrılması gibi konularda teşvik ve çalışmaları içermektedir (Black ve Baker, 2011). Hangi boyutlarla sonuçlanırsa sonuçlansın özel gereksinimi olan çocuğa sahip ailelerin yürütmüş oldukları savunuculuk faaliyeti özellikle hak elde etmek açısından oldukça faydalı olarak görülmekte ve ailelerin savunuculuk faaliyetleri sonucunda çocuklar yararına 
yüksek düzeyde sonuçlar alınmaktadır. Bu açıdan bakıldığında, özel eğitim alanında ulusal ve uluslararası yasal düzenlemeler, ailelerin savunuculuk çalışmaları sonucunda elde edilmiş kazanımlardır.

Özel gereksinimi olan çocuğa sahip aileler zaman zaman savunuculuk faaliyetlerini çeşitli etmenler yüzünden yeterince gerçekleştiremezler. Bu etmenler; aile ile Bireyselleştirilmiş Eğitim Programı (BEP) birimi arasındaki ilişki durumu, aile-okul işbirliği, ailelerin bilgi düzeyi ve yasal düzenlemelerin ülke genelinde ve okul boyutunda uygulamalara yansıması olarak ele alınmaktadır (Jackson, 2018). Bu etmenler olumlu olarak sürdüğünde aileler, çocuklarıyla ve çocukların okulunda bulunan personelle daha iyi bir etkileşim içerisine girebilmekte ve savunuculuk bağlamında daha etkili sonuçlar alabilmektedir (Larocque, Kleiman ve Darling 2011). Dünya genelinde çeşitli kuruluşlarda, merkezlerde ve programlarda ailelerin savunuculuk faaliyetlerine etki eden faktörler göz önüne alınarak, ailelere yönelik eğitimler düzenlenmekte ve aileleri savunuculuk bağlamında güçlendirmeye çalışan faaliyetler yürütülmektedir (Burke ve Hodapp, 2016).

\section{Özel eğitimde ailelerin savunuculuk rolüne tarihsel bir bakış}

Özel gereksinimi olan çocuklara yönelik olarak etkili hizmetlerin sağlanmasında ve bu hizmetlerin aile odaklı olarak yürütülmesinde ailelerin büyük bir katkısı vardır (Yılmaz Bolat, 2019). Geçmişten günümüze ailelerin özel gereksinimi olan çocuklarıyla ilgili olarak sahip oldukları hakların kazanılmasında ve önemli değişimlerin yaşanmasında ailelerin de içerisinde bizzat yer aldığı çeşitli sosyal organizasyonların ve grupların katkısı oldukça büyüktür (Özdemir, 2012). Tarihsel olarak, özel eğitim süreci ve hizmetleriyle ilgili bilgi açısından daha az güçlü olan aileler bir araya gelerek güçlenmişler ve mevzuatlara etki ederek sistem değişikliği yaratacak gücü kazanmışlardır (Turnbull ve Turnbull, 2001). Bu yönüyle savunuculuk, çocuklarına uygun eğitim firsatları yaratmaya çalışan özel gereksinimi olan çocukların ailelerinin tarihsel açıdan önemli bir sorumluluğu olmuştur. Bu konuyla ilgili ilk adımların Amerika Birleşik Devletleri’nde (ABD) atıldığı görülmektedir (Turnbull vd., 2006). Özel gereksinimi olan çocuğa sahip aileler, yirminci yüzyılın ilk yarısında çocuklarının gereksinimlerinin yeterince karşılanması ve kendileriyle benzer sorunları yaşayan ailelerle duygularını paylaşmak amacıyla çeşitli ortamlarda buluşmaya ve fikir alışverişinde bulunmaya başlamışlardır (Mclean, Sandall ve Smith, 2016). Daha sonra, aynı ya da benzer sorunları yaşayan ve benzer taleplerde bulunan ailelerin sayısının artmasıyla 1940 ve 1950'li yıllarda ABD'de çeşitli örgütlenmeler ve kuruluşların önü açılmıştır. Bu bağlamda, ilk sayılabilecek adımlardan biri, ABD'de 1949 yılında Birleşmiş Serebral Palsi Birliği'nin kurulmasıdır. Bu kuruluşun oluşumunda serebral palsili çocuğa sahip bir baba büyük ve etkin bir rol oynamıştır (Turnbull vd., 2006). Bu kuruluşu, 1961'de Amerika'nın Otizm Spektrum Bozukluğu Topluluğu ve Down Sendromu Ulusal Birliği, 1964'te Öğrenme Güçlügü olan Çocuklar Birliği ve 1988 'de Çocuk Ruh Sağlı̆̆ı için Aileler Federasyonu gibi önemli kuruluşlar takip etmiştir (Turnbull vd., 2006).

Özel eğitimin tarihsel süreci incelendiğinde, özel gereksinimi olan çocukların özel eğitime erişimi ve hizmetlerin iyileştirilmesi için aile savunuculuğunun oldukça önemli bir rol aldığ görülmektedir (Turnbull ve Turnbull, 2001). Nitekim, 1950 ile 1970 yılları arasında özel gereksinimi olan çocuklara yönelik eğitim hizmetlerinin aileler tarafından yetersiz görülmesinden dolayı, aileler de bu süreçte savunuculuk rolü bağlamında atmış oldukları adımları hızlandırmışlardır. Özellikle 1970’li yıllara gelindiğinde giderek güçlenen aileler, Yetersiz Çocuklar İçin Pennsylvania Birliği (Pennsylvania Association for Retarded Children) ve benzeri kuruluşlar, hemen her eyalette genellikle başarılı sonuçlar elde ederek özel gereksinimi olan çocuklara yönelik eğitim davalarını kazanmışlar ve ardından elde ettikleri bu kazanımlarla aileler, mahkemelerin kararını uygulamak için federal yasa gereksinimi duymaya başlamışlardır (Turnbull ve Turnbull, 1996). Yine bu konuyla ilgili sayısal olarak ABD'de 1975'ten önce 1,75 milyondan fazla özel gereksinimi olan çocuğun okuldan muaf tutulduğu, üç milyon özel gereksinimi olan çocuğa uygun bir eğitim sağlanamadığı ve zorunlu devlet okulu eğitiminin 
yalnızca tipik gelişim gösteren çocuklara uygulandığı belirlenmiştir (Yell, Rogers ve Rogers, 2006). Tüm bu olumsuzlukların ve girişimlerin sonucunda özel gereksinimi olan çocukların eğitim haklarına yönelik olarak ilk, en büyük ve köklü bir değişimi içeren 1975 tarihli Tüm Özel Gereksinimi olan Bireylerin Eğitimi Yasası (The Individuals with Disabilities Education Act [IDEA]; PL 94-142) kabul edilmiş olup, bu yasa eğitimdeki eşitsizliklerin birçok boyutunu (öneğin, kaynaştırma/bütünleştirme, erken müdahale vb.) ele almıştır (Kargın, 2004). Özel gereksinimi olan çocukların aileleri, savunuculuk yapan kuruluşlar ve kendi kendini savunan bireyler bir araya gelerek bu yasanın geçişine önemli ölçüde öncülük etmişlerdir (Rosetti vd., 2020). Daha sonraki yıllarda da yetersizlikle ilgili tüm alanları temsil eden aile örgütleri, uzmanlarla ve özellikle de Olağanüstü Çocuklar Konseyi ile güçlerini birleştirmişlerdir (Turnbull vd., 2006). IDEA'da yer alan eğitim haklarının eksikliği ve tam olarak anlaşılamaması nedeniyle bu yasayı takip eden ve o zamandan beri altı büyük değişikliğin (1978, 1983, 1986, 1990, 1997, 2001, 2004, 2008) kabulünde hedefledikleri savunuculuk faaliyetleri ile özel gereksinimi olan bireylerin aileleri oldukça kilit bir rol üstlenmiştir (Turnbull vd., 2006). Yasanın 1975 yılında kabulünün ardından ailelerin de bizzat savunuculuk yaparak mevcut yasayı düzenleme arayışları sonucunda yasanın 1986 yılındaki versiyonunda erken çocuklukta özel eğitime yönelik olarak 35 yaş arasındaki çocukların eğitiminde Bireyselleştirilmiş Aile Hizmet Planı (BAHP) vurgusu yapılmıştır (Özdemir, 2012). Ayrıca, daha önceki yasal adımlardan farklı olarak burada sadece özel gereksinimi olan çocukların değil, bunun yanı sıra ailelerinin de sürece aktif, doğrudan ve yasal katılımı sağlanmıştır. IDEA'da, 2004 yılında yapılan düzenlemeler ile okul-aile işbirliği ve ailenin eğitim süreçlerine etkin katılımı konusuna açıkça vurgu yapılmıştır (Burke ve Sandman, 2015). Özel eğitim hizmetlerinde yasal süreçler ve roller değiştikçe özel gereksinimi olan çocuğa sahip aileler de dinamik bir şekilde savunucu olmaya devam etmiştir. Özel Eğitim ile ilgili mevcut yasalar incelendiğinde, özel gereksinimi olan çocukların eğitim hakkına yönelik kararların alınmasında ailelerin çabalarının büyük etkisinin olduğu görülmektedir. Bununla birlikte özel eğitimle ilgili olarak aileler tarafından zaman zaman karmaşık olarak algılanabilecek yasal bir boyut sürecini de beraberinde getirmiştir (Mueller, 2009). Bu noktada yasaları anlamak için aileler, ek bir uzmanlığa ihtiyaç duymuşlar ve böylece sistemli özel eğitim savunuculuğu ortaya çıkmıştır (Nachshen, Anderson ve Jamieson, 2001).

Aile savunuculuğu konsunda 2000'li yıllara gelindiğinde ise ABD'nin farklı noktalarında faaliyet gösteren 106 Ebeveyn Eğitim ve Bilgi Merkezinin, özel gereksinimi olan çocukların ailelerine özel eğitim hizmetleriyle ilgili yasal hakları konusunda bilgi verdikleri görülmüştür (Burke ve Hodapp, 2016). Bu tür merkezler ve programların tamamı, özel gereksinimi olan çocukların ailelerinin özellikle stratejik savunuculuk rolünü geliştirmeye odaklanmakta; bunun için ailelere özel eğitim ile ilgili kanunları, politikaları ve ailelerin kendilerine ve çocuklarına verilen hakları etkili bir şekilde nasıl kullanacakları öğretilmektedir (Burke, 2013). Örneğin, ABD'de Özel Eğitim Savunuculuk Eğitimi (Special Education Advocacy Training) programı ile özel eğitim konusunda savunucular yetiştirmek hedeflenmektedir. Buna ek olarak, ABD'de kurumların daha fazla sayıda özel eğitim savunucusu yetiştirme isteği ve çabasına bağlı olarak, 2008 yılında başlı başına bir savunuculuk eğitimi projesi olan Gönüllü Savunuculuk Projesi (Volunteer Advocacy Project) geliştirilmiş̧ir (Burke vd., 2019). ABD’de o yıllardan beri aileler, özel gereksinimi olan çocuklarının eğitim süreçleriyle ilgili olarak savunuculuk rollerini geliştirmeleri için ilgili programlar ve projeler aracılığıyla eğitilmektedir (Goldman, Burke, Mason ve Hodapp, 2017).

Özel eğitimde savunuculukla ilgili Türkiye'deki durum incelendiğinde, yasaların kabulünden önceki süreçlerde bazı aileler savunuculuk faaliyetleri kapsamında bireysel olarak savunuculuk yapsa da genel olarak toplumda ailelerin sistemli bir savunuculuk faaliyeti içerisine girmediği görülmektedir. Yasal düzenlemeler incelendiğinde, 1983 yılından bu yana tıpk1 gelişmiş bazı ülkelerde olduğu gibi Türkiye'de de özel eğitim ve özel gereksinimi olan çocukların kaynaştırma/bütünleştirme yoluyla eğitim alması önem taşımaya başlamıştır (Sarı, 2002). Türkiye' de 1997 yılında yürürlüğe giren 573 sayılı Kanun Hükmünde Kararname (KHK) ile özel gereksinimi olan çocukların eğitimlerinin yanı sıra ailelerinin de bu eğitim sürecinin her boyutuna 
aktif olarak katılımı sağlanmıştır (Özdemir, 2012). Böylece, özel gereksinimi olan bireylerle ilgili özel eğitim hizmetleri ve ailelerinin sürece dahil edilmesi ile ilgili yasal hak ve güvenceler uluslararası olayları ve gelişmeleri takiben Türkiye' de de yasallaşmıştır. Tipik gelişim gösteren çocukların eğitimi konusunda ailelere destek olan ve aileleri genel olarak eğitim hakkında bilinçlendiren ulusal çapta projeleri içeren ilk çalışma olarak Anne Çocuk Eğitim Vakfı (AÇEV) bünyesinde yapılan çalışmaların olduğu görülmektedir (AÇEV, 2020). AÇEV'e üye olan özel gereksinimi olan çocuğa sahip annelerin de vakıf bünyesindeki erken çocukluk eğitimleri konularında eğitimlere katılarak özel gereksinimi olan çocuklarının eğitim süreçleriyle ilgili dolaylı yoldan bilgi edinmektedirler. Ancak burada ailelerin savunuculuk faaliyetleri içerisinde yer almadıkları ya da savunuculuk rollerine katkı sağlayacak bir eğitim almadıkları bilinmektedir.

Türkiye' de 2000'li yıllara gelindiğinde ise 2003 yılında Tohum Otizm Vakfı isminde; erken tanı ve müdahale, topluma kazandırma gibi konularda otizm spektrum bozukluğu olan çocuklar ve aileleri için çalışan ve ayrıca savunucu rolü de gören bir vakıf kurulmuştur. Buraya gönüllü olarak üye olan aileler, çocukları hakkında çeşitli çalışmaları gerçekleştirmekte, bu kuruluşa çeşitli yollarla destek sağlamakta ve savunucu faaliyetlerde yer almaktadır. Vakıf günümüzde halen aktif olarak çalışmalarını sürdürmekte ve birçok aile tarafından destek görmektedir. Tohum Otizm Vakfi aracılığıyla, Eğitime Uzanan Yol Projesi kapsamında 2017-2019 yılları arasında 20 ilde yaklaşık 1600 aile bireyine özel gereksinimi olan çocukların hakları konusunda eğitimler düzenlenmiştir (Tohum Otizm Vakfi, 2020). Bu vakıf, çeşitli sivil toplum kuruluşlarının da desteğini alarak, Türkiye' de 03.12.2016 tarih ve 29907 sayılı Resmi Gazete' de yayınlanmış olan Otizm Spektrum Bozukluğu (OSB) olan bireylere yönelik Ulusal Otizm Eylem Planı'nın yürürlüğe girmesi konusunda aktif rol oynamıştır (Aile ve Sosyal Politikalar Bakanlığı, 2020). $\mathrm{Bu}$ eylem planının içerisinde; (1) OSB olan çocuğa sahip ailelerin bilgilendirilmesi, bilinçlendirilmesi, eğitilmesi ve yönlendirilmesi ile birinci basamak sağlık kuruluşlarında aile destek birimleri kurularak, bu birimlerde görevli uzmanlarca aile danışmanlığının sağlanması; (2) erken tanı, tedavi ve müdahale zincirinin kurulması; (3) ailelere yönelik bakım, sosyal hizmet ve yardım konularında bilgilendirme yapılması; (4) eğitim ve danışmanlık hizmeti verilmesi için gerekli adımların atılması; (5) Aile ve Sosyal Politikalar Bakanlığ 1 web sitesinde ailelere yönelik uzaktan eğitim programının sunulması; (6) bir web portalının oluşturulması ve kanıt temelli uygulamaların sağlanması gibi konularda adımlar atılması kararlaştırılmıştır (Melekoğlu, 2019; Yüksek Planlama Kurulu, 2016). Bu eylem planı içerisinde yer alan ve OSB olan çocuğa sahip ailelere yönelik geliştirilen planlamaların aileleri bilinçlendirmek ve güçlendirmek yoluyla katılımlarını sağlamayı hedeflediği söylenebilir. Buna ek olarak, Türkiye'de aileleri, özel gereksinimi olan çocuklarının hakları konusunda destekleyen ve bilgi sağlayan çeşitli sivil toplum kuruluşları da bulunmaktadır. Bunlar arasında, Down Sendromlular Derneği, Türkiye Zihinsel Yetersiz Çocukları Yetiştirme ve Koruma Vakfı (ZİÇEV), Özel Eğitimciler Derneği (ÖZDER) gibi farklı yetersizlik türlerine göre kurulan dernekler mevcuttur. Bu dernekler, Engelli Çocuk Hakları Ağı, Eğitimde Eşit Haklar Platformu gibi yetersizliği olan bireylerin hakları alanında çalışmalar yapan çeşitli platformlarda aktif görev almakta ve savunuculuk faaliyetleri gerçekleştirmektedir. Ayrıca derneklerin çoğu, özel gereksinimi olan çocukların ailelerinin bir hak ihlali yaşamaları durumunda ailelere destek sağlamaktadır. Diğer yandan, Türkiye'de ailelerin savunuculuk rolünü güçlendirmeyi amaçlayan ulusal düzeyde herhangi bir eğitim programı bulunmamaktadır.

\section{Tartışma, Sonuç ve Öneriler}

Gerek tipik gelişim gösteren, gerekse özel gereksinimi olan çocuğu olan ailelerin çocukları ile ilgili ebeveynlik, ögretmenlik ve savunuculuk gibi bir takım rolleri bulunmaktadır. Ancak özel gereksinimli çocukların aileleri bu rolleri yerine getirmek için diğer ailelere oranla daha yoğun uğraşlar vermektedir (Turnbull vd., 2006). Özel gereksinimi olan çocukların ailelerinin, çocuklarının uygun hizmelere erişimi konusunda özellikle savunuculuk rolleri bağlamında daha fazla emek sarf etmeleri gerekmektedir. Her aile savunucu rolü için yeterli imkan, bilgi ve donanıma sahip değildir ancak aileler hayatlarının belirli bir döneminde ya da anında her ne kadar sistemli ve gelişmiş bir savunuculuk olmasa da çocuklarının ihtiyaçları için bir noktada 
savunuculuk rolüne başvurmaktadır. Çocuklarının sahip oldukları özel gereksinime dayalı olarak, her ailenin eğitsel ve sosyal anlamda olumsuz durumlarla karşı karşıya kaldığ durumlar olabilmektedir. Aileler bu durumların üstesinden gelebilmek, çocukları için iyi bir yaşam koşulu sağlamak, engellerin ortadan kalkması ve tam bir firsat eşitliği sağlanması için savunuculuk rolünün aileler tarafindan etkili bir şekilde kullanılmasına gereksinim vardır. Bu nedenle gerek dünya çapında gerekse Türkiye'de aileleri, savunucu olarak güçlendiren ve bilinçlendiren daha fazla sayıda ve türde savunuculuk eğitimlerinin ve projelerinin yürütülmesine ve yaygınlaştırılmasına ihtiyaç vardır. Bunun için aileler; (1) çocuklarının ve kendilerinin yasal hakları, (2) haklarını yasal olarak arama yolları, (3) özel eğitim hizmetleri ve hizmetlere erişim bilgileri gibi konular hakkında bilgilendirilebilir. Türkiye'de, ailelerin çocuklarının eğitim sürecine daha aktif katılımları konusunda eğitimler planlanabilir. $\mathrm{Bu}$ bağlamda, okul-aile işbirliğinin güçlendirilmesine yönelik çalışmalar yapılabilir. Türkiye'de özel gereksinimi olan çocuklarla ilgili yerel ve ulusal düzeyde dernekler bulunmaktadır ancak bu derneklerin daha işlevsel olması açısından çalışmalar yürütülebilir. Böylece, dernekler özel eğitim ile ilgili yeni politikaların geliştirilmesinde öneriler geliştirebilir. Sonuç olarak, ailelere uygun eğitimler sağlanarak ve uygun yönlendirmeler yapılarak ailelerin uzmanlarla işbirliği içerisinde çalışması sağlanmalıdır.

\section{Etik Kurul Onay Bilgileri}

Bu çalışma, bir derleme çalışması olduğu için etik kurul izninden muaftır.

\section{Çıkar Çatışması}

Yazarlar, bu çalışma kapsamında herhangi bir çıkar çatışmasının olmadığını beyan etmişlerdir.

\section{Finansal Destek}

Yazarlar, bu çalışma için herhangi bir finansal destek almadıklarını beyan etmişlerdir.

\section{Kaynaklar}

Akçamete, G. ve Kargın, T. (1996). İşitme engelli çocuğa sahip annelerin gereksinimlerinin belirlenmesi. Ö̈el Ĕ̈itim Dergisi 2(2), 7-24.

Aile ve Sosyal Politikalar Bakanlığı. (2020). Otizm spektrum bozukluğu olan bireylere yönelik ulusal eylem planı. https://www.aile.gov.tr/yalova/haberler/otizm-spektrum-bozukluguolan-bireylere-yonelik-ulusal-eylem-plani-toplantisi-yapildi/ adresinden erişilmiştir.

Anne Çocuk Eğitim Vakfi. (2020). Anne destek programı. https://www.acev.org/neyapiyoruz/anne-babalar-icin/anne-destek-programi/ adresinden erişilmiştir.

Aydoğan-Akıncı, A. ve Darıca, N. (2000). Özürlü çocuğa sahip anne-babaların umutsuzluk düzeylerinin incelenmesi. Çocuk Forumu Dergisi, 3(2), 25-31.

Başbakanlık Aile Araştırma Kurumu. (1990). 1. Aile şurası: Raporlar, görüşmeler, kararlar. Ankara: Aile Araştırma Kurumu Yayınları.

Black, A. P., \& Baker, M. (2011). The impact of parent advocacy groups, the internet, and social networking on rare disease: The IDEA League and United Kingdom example. Epilesia, 52(2), 102-104.

Blacher, J., \& Hatton, C. (2001): Current perspectives on family research in mental retardation. Current Opinion in Psychiatry, 14(1), 477-482.

Bronfenbrenner, U. (1986). Ecology of the family as a context for human development: Research perspectives. Developmental Psychology, 22(6), 723-742.

Burke, M. M. (2013). Improving parental involvement: Training special education advocates. Journal of Disability Policy Studies, 23(1), 225-234.

Burke, M. M., \& Hodapp, R. M. (2016). The nature, correlates, and conditions of parental advocacy in special education. Exceptionality, 24(1), 137-150.

Burke, M.M., Lee, C.E., \& Rios, K. (2019). A pilot evaluation of an advocacy programme on knowledge, empowerment, family-school partnership and parent well-being. Journal of Intellectual Disability Research, 63(8), 969-980. 
Burke, M. M., \& Sandman, L. (2015). In the voices of parents: Suggestions for the next IDEA reauthorization. Research and Practice for Persons with Severe Disabilities, 40(1), 7185.

Cavkaytar, A. (2012). Toplum ve aile. A. Cavkaytar (Ed.), Özel eğitimde aile eğitimi ve rehberliği içinde (ss. 3-18). Ankara: Vize Yayıncılık.

Cohen, S. R. (2013). Advocacy for the 'Abandonados': Harnessing cultural beliefs for Latino families and their children with intellectual disabilities. Journal of Policy and Practice in Intellectual Disabilities, 10(1), 71-78.

Conley Wright, A., \& Taylor, S. (2014). Advocacy by parents of young children with special needs: Activities, processes, and perceived effectiveness. Journal of Social Service Research, 40 (5), 591-605.

Ergün, M. (1987). Eğitim ve toplum: Eğitim sosyolojisine giriş. Malatya: İnönü Üniversitesi Yayınlar1.

Fiedler, C. R., Simpson, R. L., \& Clark, D. M. (2007). Effective school-based support service. In Parents and families of children with disabilities (pp. 1-352). New Jersey, NJ: Pearson Merrill Prentice Hall.

Goldman, S. E., Burke, M. M., Mason, C. Q., \& Hodapp, R. M. (2017). Correlates of sustained volunteering: Advocacy for students with disabilities. Exceptionality, 25(1), 40-53.

Gökçe, B. (1991). Aile ve aile tipleri üzerine bir inceleme. B. Dikeçligil ve A. Çiğdem (Ed.), Aile yazıları: Temel kavramlar, yapı ve tarihi süreç içinde. Ankara: T.C. Başbakanlık Aile Araştırmaları Kurumu Yayınları.

Hooper, S., \& Umansky, W. (2004). Young children with special needs (pp. 3-13). New Jersey, NJ: Pearson Education, Inc.

İlhan, T. (2017). Özel gereksinimli 3-6 yaş çocukların ebeveynlerinin stres düzeyleri ile rolleri arasındaki iliş̧ki. Ankara Üniversitesi Eğitim Bilimleri Fakültesi Özel Eğitim Dergisi, $18(3), 383-400$.

Jackson, T. (2018). Evaluating the role of family involvement and the impact of parental advocacy on success of elementary school students with disabilities. (Unpublished doctoral dissertation). Delaware, DE: Delaware State University.

Kalyanpur, M., \& Harry, B. (1999). Building reciprocal family professional relationships. In Culture in special education (pp. 1-159). Maryland, MD: Paul H. Brookes Publishing.

Kargın, T. (2004). Kaynaştırma: Tanımı, gelişimi ve ilkeleri. Ankara Üniversitesi Ĕgitim Bilimleri Fakültesi Özel Eğitim Dergisi, 5(2) 1-13.

Kır, İ. (2011). Toplumsal bir kurum olarak ailenin işlevleri. Elektronik Sosyal Bilimler Dergisi, 10(36), 381-404.

Larocque, M., Kleiman, I., \& Darling, S. M. (2011). Parental involvement: The missing link in school achievement. Preventing School Failure, 55(3). 115-122.

McCammon, S. L., Spencer, S. A., \& Friesen, B. J. (2001). Promoting family empowerment through multiple roles. Journal of Family Social Work, 5(3), 1-24.

McGahee, M., Mason, C., Wallace, T., \& Jones, B. (2001). Student-led IEPs: A guide for student involvement. Council for Exceptional Children. Arlington, VA: Minnesota University. Retrieved from https://files.eric.ed.gov/fulltext/ED455623.pdf

McLean, M., Sandall, S.R., \& Smith, B. J. (2016). A history of early childhood education. In B. Reichow, B. A. Boyd, E. E. Barton, S. L. Odom (Ed.), Handbook of early childhood special education (pp. 3-20). Switzerland: Springer International.

Melekoğlu, M., Kırıcı, E., Kartal, H. ve Tekin, H. A. (2018). Özel gereksinimli çocuğu olan ailelerin yaşadıkları deneyimlere göre geçmişten günümüze çocuğu değerlendirme süreci. M. A. Melekoğlu (Ed.), 28. Ulusal özel eğitim kongresi tam metin bildiri kitabı içinde (s. 65-76). Eskişehir. ISBN: 978-605-80966-0-8

Melekoğlu, M. A. (2019). Zihin yetersizliği ve otizm spectrum bozukluğu hakında yasal düzenlemeler. M. A. Melekoğlu ve M. Sönmez Kartal (Ed), Zihin yetersizliği ve otizm spektrum bozukluğu içinde (ss.258-281). Ankara: Pegem Akademi Yayınları. 
Meral, B. F. ve Cavkaytar, A. (2013). Beach center aile yaşam kalitesi ölçeğinin Türkçe uyarlama, geçerlik ve güvenirlik çalışması. Eğitim ve Bilim, 38(170), 48-60.

Mueller, T. G. (2009). Alternative dispute resolution: A new agenda for special education policy. Journal of Disability Policy Studies, 20(1), 4-13.

Nachshen, J. S., Anderson L., \& Jamieson, J. (2001). The parent advocacy scale: Measuring advocacy in parents of children with special needs. Journal of Developmental Disabilities, 8, 93-105.

Özdemir, O. (2012). Ailelerin danışmanlık, rehberlik ve eğitim gereksinimlerinin karşılanması. A. Cavkaytar (Ed.), Özel ĕgitimde aile eğitimi ve rehberlĭgi içinde (ss. 179-213). Ankara: Vize Yayinc1lik.

Phillips, E. (2008). When parents aren't enough: External advocacy in special education. Yale Law Journal, 117, 1802-1853.

Poston, D., Turnbull, A., Park, J., Mannan, H., Marquis, J., \& Wang, M. (2003). Family quality of life: a qualitative inquiry. Mental Reterdation, 41(5), 313-328.

Rosetti, Z., Burke, M. M., Rios, K., Tovar, J. A., Scrahaml-Block, K., Rivera, J. I., Cruz, J., \& Lee, J. D. (2020-Early Publication). From individual to systemic advocacy: Parents as change agents. Exceptionality. doi:10.1080/09362835.2020.1850456

Sarı, H. (2012). Özel ĕgitime muhtaç ögrencilerin ĕgitimleriyle ilgili öneriler. Ankara: Pegem Akademi Yayınları.

Schaefer, R. T. (2013). Sosyoloji. Simten Coşar (Çev. Ed.). Ankara: Palme Yayıncılık.

Sucuoğlu, B. (1996). Kaynaştırma programlarında anne-baba katılımı. Özel Eğitim Dergisi, 2(2) 25-43.

Summers, J. A., Poston, D. J., Turnbull, A. P., Marquis, J., Hoffman, L., Mannan, H., \& Wang, M. (2005). Conceptualizing and measuring famil quality of life. Journal of International Disability Research, 49(10), 777-783. doi:10.1111/j.1365-2788.2005. 00751.x

Tavil, Y. Z. (2005). Davranış denetimi aile eğitim programının annelerin davranışsal işlem süreçlerini kazanmalarına etkisi (Yayınlanmamış doktora tezi). Gazi Üniversitesi, Eğitim Bilimleri Enstitüsü, Ankara.

Tezcan, M. (1985). Eğitim Sosyolojisi. Ankara: Ankara Universitesi Basımevi.

Tohum Otizm Vakfi. (2020). Eğitime uzanan yol projesi. https://www.tohumotizm.org.tr/ adresinden erişilmiştir.

Trainor, A. (2010). Diverse approaches to parent advocacy during special education home-school interactions: Identification and use of cultural and social capital. Remedial and Special Education, 31(1), 34-47. doi: 10.1177/0741932508324401

Turnbull, A.P., \& Turnbull, H.R. (1996). Families, profesionals and exceptionality. NJ: PrenticeHall Inc.

Turnbull, A., \& Turnbull, R. H. (2001). Families, professionals and exceptionality: Collaborating for empowerment (4th ed.). Upper Saddle-River, NJ: Prentice-Hall.

Turnbull, A., Turnbull, R., Erwin, E., \& Soodak, L. (2006) Families, professionals, and exceptionality: Positive outcomes through partnerships and trust. Upper Saddle River, NJ: Merrill/Prentice Hall.

Yell, M., Rogers, D., \& Rogers, E. L. (2006). The history of the law and children with disabilities. Upper Saddle River, NJ: Prentice-Hall.

Y1lmaz Bolat, E., Gürsoy, F., ve Strom, R. (2016). Öğretmen Olarak Anne Baba Envanteri: Geçerlik ve Güvenirlik Çalışması. Mersin Üniversitesi Ĕgitim Fakültesi Dergisi, 2016; 12(3), 961-970. doi: 10.17860/mersinefd.282394

Yılmaz Bolat, E. (2019). Özel eğitim ve kaynaştırma. Ankara: Nobel Akademik Yayıncılık.

Yüksek Planlama Kurulu. (2016). Otizm spektrum bozukluğu olan bireylere yönelik ulusal eylem planı (2016-2019), 03.12.2016 tarih ve ve 29907 sayılı Resmi Gazete.

Zaretsky, L. (2004). Advocacy and administration: From conflict to collaboration. Journal of Educational Administration, 42(2), 270-286. 


\section{Introduction}

\section{Extented Abstract}

Family, which has an important place in the development of a child, is seen as an important institution based on society (Tavil, 2005). When the literature is examined, it is seen that the definition of the concept of family is made in various ways, since the definitions for the meaning of the concept of family are not universal and there isn't a single definition regarding the family (Cavkaytar, 2012). The Prime Ministry Family Research Institution defines the family as a social institution consisting of individuals living in the same environment, where marriage and kindship loyalty is formed based on a legal basis (Prime Ministry, 1990). Considering the definitions made in general, it can be said that the definition of family has moved away from traditionalism and changed depending on social change in time. Although the definitions of the family have changed, it cannot be said that there has been much change in the functions of the family from past to present, especially for the child they are responsible for. As is known, the family in which a child grows up has basic functions (Blacher Hatton, 2001). "These functions are generally considered as meeting economic needs, providing status, planning the education of children, giving religious education, performing leisure activities, protecting family members and creating an atmosphere of mutual love" (Cavkaytar, 2012, s. 9). Although situations such as the developmental characteristics of the child, the presence of a special situation, and biological ties between child and family sometimes cause differences in the function of family, there is no change in the basic functions of families (Turnbull, 2006). In this context, the roles undertaken by families in the development processes of children with special needs, which differ significantly in their development compared to their peers without disabilites, are very important (İlhan, 2017). For this reason, the need for families of children with special needs may be higher than the children without disabilities from time to time (Aydoğan-Akıncı \& Darıca, 2000).

Families can support their children with special needs in various ways and while providing this support, they adopt various roles at different levels. Families teach their children with special needs, try to promote special education and disability groups by collaborating with voluntary organizations related to disability, taking a leading role in the opening of various special education schools, acting as political advocates, making educational decisions for their children and also parents of children with similar characteristics. Collaborating with other parents and guiding other parents for the education of their children (Sucuoğlu, 1996).With the inclusion of an individual with special needs in a family, various needs of families arise based on issues related to disability, and it is seen that these needs are about information, social support, and economic needs (Akçamete \& Kargın, 1996). Families of children with special needs feel complex emotional situations after their children are diagnosed as special needs, because they do not know where to get support from (Ar1 et al., 2012). At this point, families may be insufficient in terms of the measures to be taken for their children and they can adopt the role of advocating for their children (Burke \& Hodapp, 2016). It is known that there are different studies in the field of special education that address the rights advocacy role of families in various dimensions. However, there is no study on this issue in Turkey that deals with the advocacy role process of families of children with special needs in the historical overwiev. In this study, the advocacy role of families of children with special needs, the importance of this role, and the contributions of families to children with special needs through advocacy are discussed in the context of national and international literature in the historical overwiev.

\section{Families as advocates}

Advocacy is defined as accepting perceptions of an individual or perceptions of another person to achieve the desired result that cannot be achieved through other means (Turnbull \& Turnbull, 2001). In terms of protecting legal rights of children with special needs, families of children are seen as natural advocates for them (McCammon et al., 2001). Worldwide, family advocacy is seen as an effective initiative method to facilitate and improve the access of children with special 
needs to the services they need in response to the negative situations they experience about their disabilities (Cohen, 2013).

\section{Historical perspective on advocacy role of parents in special education}

Families have a great contribution in providing effective services for children with special needs and in carrying out these effective services in a family-oriented manner (Bolat, 2019). Historically, families has gained powerful strength by coming together and creating system change in the form of legislation about special education services (Turnbull \& Turnbull, 2001). In this respect, advocacy has historically been an important responsibility of families of children with special needs trying to create appropriate educational opportunities for their children. For this, the first steps regarding this issue were taken in the United States of America (USA) (Turnbull, 2006). In the first half of the twentieth century, families of children with special needs started to meet and exchange ideas in various environments to meet the needs of their children adequately and to share their feelings with families experiencing similar problems (Mclean et al., 2016). The United Cerebral Palsy Association was established in the USA in 1949 as one of the first steps that can be considered in this regard. These organizations were followed by important organizations such as the Autistic Society of America and the National Association of Down Syndrome in 1961, the Association of Children with Learning Disabilities in 1964, and the Federation of Families for Child Mental Health in 1988 (Turnbull et al., 2006).

Families accelerated the steps they took in advocacy between 1950 and 1970, especially as they saw education services for children with special needs as inadequate. Families of children with disabilities got stronger in the 1970s (Turnbull \& Turnbull, 1996; Yell et al., 2006). As a result of all these negativities and initiatives, the Individual Education Act [IDEA] (PL 94-142) of 1975, which contains the first, biggest, and radical change in the education rights of children with special needs has been accepted (Rosetti et al., 2020). In the following years, family organizations representing all areas related to disability joined forces with professionals and especially with the Council of Extraordinary Children (Turnbull, 2006). As legal processes and roles in special education services changed, families with children with special needs had to dynamically continue to be advocates (Mueller, 2009).

In the 2000s, educating families of children with disabilities about their rights regarding special education services has become the task of 106 Parent Education and Information Centers operating in different parts of the USA (Burke \& Hodapp, 2016). All such centers and programs focus especially on developing the strategic advocacy of families of children with special needs, and in existing centers, it is aimed to teach the participants the laws and policies regarding special education and how to use the rights given to them and their children effectively (Burke, 2013). When looking at Turkey on this issue, it is seen that some families advocated individually in advocacy activities in Turkey before the adoption of laws, but generally, families did not engage in systematic advocacy activity. Considering the legal regulations, the education of children with special needs has become important in Turkey since 1983, just like in some developed countries (Sar1, 2002). With the Decree-Law No. 573, which entered into force in 1997 in Turkey, in addition to the education of children with special needs and their families have also actively participated in all aspects of education process (Özdemir, 2012).

When it came to the 2000s in Turkey, a foundation was established in 2003, named Tohum Autism Foundation. It works for children with autism spectrum disorders and their families on issues such as early diagnosis and intervention, reintegration into society, and also acts as an advocate. Families who become members of this group voluntarily carry out various studies about their children, provide support to this organization in various ways and take part in advocacy activities.

\section{Result and Discussion}

As a result, families of children with special needs have adopted various roles since the beginning of their children's education process such as advocacy role in some way (Turnbull et al., 2006). 
Not every family has sufficient opportunities, knowledge, and equipment for the advocacy role, but families resort to the role of advocate for their child's needs at some point, even though there is no systematic and sophisticated advocacy at a particular time or moment in their lives. Considering that every family may face negative situations in educational and social life based on the special needs of their children, the advocacy role must still be used effectively by families to overcome these situations, provide a good living condition for children, remove barriers and ensure full equality of opportunity. Regarding this issue, there is a need to carry out and disseminate more and more advocacy training and projects that strengthen families as advocates and raise awareness in Turkey and around the world. 